\title{
On the Amazonian species of the genus Scytodes Latreille (Arachnida, Araneae, Scytodidae)
}

\author{
Cristina A. Rheims ${ }^{1,2}$ \& Antonio D. Brescovit ${ }^{1}$
}

${ }^{1}$ Laboratório de Artrópodes, Instituto Butantan. Avenida Vital Brasil 1500, 05503-900 São Paulo, São Paulo, Brasil. E-mail: cris.rheims@butantan.gov.br; adbresc@terra.com.br

${ }^{2}$ Departamento de Zoologia, Instituto de Biociências, Universidade de São Paulo. Rua do Matão, Travessa 14, 101, 05508-900 São Paulo, São Paulo, Brasil.

\begin{abstract}
Eight species of Scytodes Latreille, 1804 are newly described: Scytodes iara sp. nov. and S. caure sp. nov. from Amazonas; S. mapinguari sp. nov. from Amazonas and Roraima; S. curupira sp. nov. from Amazonas and Rondônia; S. saci sp. nov. from Roraima; and S. jurupari sp. nov., S. tinkuan sp. nov. and S. caipora sp. nov. from Acre. In addition, the female of $S$. altamira Rheims \& Brescovit, 2000 is described and new records are presented for $S$. auricula Rheims \& Brescovit, 2000, S. fusca Walckenaer, 1837, S. longipes Lucas, 1844, S. martiusi Brescovit \& Höfer, 1999, S. piroca Rheims \& Brescovit, 2000, S. romitii Caporiacco, 1947 and S. vieirae Rheims \& Brescovit, 2000.

KEY WORDS. Neotropical, spitting spiders, taxonomy.
\end{abstract}

RESUMO. Oito novas espécies de Scytodes Latreille, 1804 são descritas: Scytodes iara sp. nov. e S. caure sp. nov. do Amazonas; S. mapinguari sp. nov. do Amazonas e de Roraima; S. curupira sp. nov. do Amazonas e de Rondônia; $S$. saci sp. nov. de Roraima; e $S$. jurupari sp. nov., S. tinkuan sp. nov. e S. caipora sp. nov. do Acre. A fêmea de $S$. altamira Rheims \& Brescovit, 2000 é descrita e novos registros são apresentados para S. auricula Rheims \& Brescovit, 2000, S. fusca Walckenaer, 1837, S. Iongipes Lucas, 1844, S. martiusi Brescovit \& Höfer, 1999, S. piroca Rheims 8 Brescovit, 2000, S. romitii Caporiacco, 1947 e S. vieirae Rheims \& Brescovit, 2000.

PALAVRAS CHAVE. Aranhas-cuspideiras, neotropical, taxonomia.

According to Platnick (2003), the family Scytodidae includes to date 157 species, in five genera, of which Scytodes Latreille, 1804 is by far the largest, with 152 known species. The genus is widespread in the Neotropical region and includes several synanthropic species (BREsCovit \& RHeIMS 2000).

Until the year 2000, the genus included 43 neotropical species, of which 10 were described exclusively from Brazil and five presented distribution ranges that included the Brazilian territory (BRescovit \& Rheims 2000). Between 2000 and 2002, several papers were published concerning the Brazilian scytodid fauna (Brescovit \& RHeims 2000, Rheims \& Brescovit 2000, 2001a, b), thus increasing the number of Brazilian species to 18 and seven, respectively.

This is the first of a series of papers dealing with the scytodid fauna of the different fitogeographical regions of Brazil. It covers the scytodid fauna from the Amazonian region complementing the initial surveys presented by BREsCovit \& Höfer (1999) and Rheims \& Brescovit (2000). The Brazilian Amazonia includes the states of Amazonas, Pará, Acre, Rondônia and Amapá as well as western Tocantins, western
Maranhão and northern Mato Grosso (Fernandes 1998). It is characterized by extense forested areas, reasonably high temperatures year round and high pluviometric indices (FERNANDES 1998, Ав'SÁBER 2003).

Nine species have been described from the Amazonian region: S. paarmani and S. martiusi, from Reserva Florestal Adolpho Ducke and $S$. janauari from Lago Janauari, all from Manaus, Amazonas, described by HöFer \& BRescovit (1999); $S$. piroca, $S$. auricula and $S$. vieirae, from Parque Nacional da Serra do Divisor, Acre; S. balbina from Balbina and S. mapia from Borba, both in Amazonas; and S. altamira from Altamira, Pará, all described by Rheims \& Brescovit (2000). Besides these, six other species present distribution ranges that include the Brazilian Amazonia: S. fusca Walckenaer, 1837, S. itapevi Brescovit \& Rheims, 2000, S. lineatipes Taczanowski, 1874, S. longipes Lucas, 1844, S. championi F.O.P.-Cambridge, 1899 and S. romitii Caporiacco, 1947. In this paper we present the description of eight new species of Amazonian Scytodes, as well as the description of the female of $S$. altamira. In addition we present new records for the known species occuring in the Amazon region. 


\section{MATERIAL AND METHODS}

The material examined belongs to the following institutions: (AMNH) American Museum of Natural History, New York, N.I. Platnick; (IBSP) Instituto Butantan, São Paulo, I. Knysak; (INPA) Instituto Nacional de Pesquisa da Amazônia, Manaus, C. Magalhães; (MCTP) Museu de Ciências e Tecnologia, Pontifícia Universidade Católica do Rio Grande do Sul, Porto Alegre, A.A. Lise; (MCZ) Museum of Comparative Zoology, Cambridge, G. Giribet and L. Leibensperger; (MPEG) Museu Paraense Emílio Goeldi, Belém, A.B. Bonaldo; (MZSP) Museu de Zoologia de São Paulo, São Paulo, R. Pinto da Rocha; (UA) Universidade do Amazonas, Manaus, N.O. Aguiar. Descriptions and terminology follow Brescovit \& Rheims (2000). All measurements are in millimeters. Epigynes were dissected and submerged in clove oil to study internal structures.

\section{Scytodes altamira Rheims \& Brescovit, 2000 Figs 1-3}

Scytodes altamira Brescovit \& Rheims, 2000: 729, figs 4G-H (male holotype from Cachoeira, Altamira, Pará, Brazil, deposited in IBSP 4212, examined). - Platnick, 2003 (electronic cata$\log )$.

Diagnosis. The females of $S$. altamira resemble those of S. mapia Rheims \& Brescovit (2000: 727, fig. 4E-F) by the small rounded spermathecae and semicircle hyaline pocket. They are distinguished by the straight and narrow positioning ridges and by the spermathecae, partially covered by the hyaline pockets (Figs 2-3).

Description. Male described by Rheims \& BREscovit (2000).

Female (IBSP 39372). Carapace pale yellow with brown pattern as shown on figure 1. Chelicerae yellowish with dorsal longitudinal brown stripe. Pedipalps pale yellow. Palpal patellae and tibiae with dorsal and prolateral brown stripes. Labium pale yellow, brown at base. Endites pale yellow. Sternum cream coloured with brown margins in front of each coxae and labium. Legs yellowish, except patellae brown. Femora and tibiae I-IV with ventral longitudinal brown stains. Tibiae I-IV with median transversal brown bands and brown distal ends. Abdomen gray with very thin transversal lines at posterior end (Fig. 1). Total length 6.80. Carapace domed, 3.10 long, 2.60 wide. Eye diameters: PME 0.18, ALE 0.16, PLE 0.18. Lateral eyes on a tubercle. Chelicerae with subapical hyaline keel and eight conspicuous stridulatory ridges. Labium 0.24 long, 0.32 wide. Sternum 1.64 long, 1.16 wide. leg measurements: I - femur 6.20/ patella $0.80 /$ tibia $6.50 /$ metatarsus $8.00 /$ tarsus $0.90 /$ total 22.20 / II $-4.40 / 0.80 / 4.30 / 5.00 / 0.80 / 15.30 / \mathrm{III}-2.90 / 0.80 / 2.50 / 2.90 /$ 0.70/9.80/IV - 4.30/0.80/4.00/4.70/0.80/14.60. Palpal femur with stridulatory pick short and stout on triangular and projected socket. Internal genitalia with small, rounded spermathecae partially covered by a large semicircular hyaline pocket. Copulation ducts inconspicuous (Fig. 3). Abdomen 3.70 long, 3.30 wide, covered with slender hairs.
Variation. Six males. Total length: 4.8-5.40; carapace: 2.50-2.80; femur I: 9.40-10.20; bulb: 0.90-0.96. Six female. Total length: 4.40-6.90; carapace: 2.40-3.40; femur I: 5.70-6.40.

Distribution. Northern Brazil, states of Pará and Amazonas.

Material Examined. Amazonas: BR 174, $80 \mathrm{Km} \mathrm{N}$ from Manaus, Fazenda C. Powell, 1 male, May 6, 2002, F. Rego leg. (INPA); Reserva do Km 41, 1 male, May 5, 2002, F. Rego leg. (INPA); Reserva Florestal, 1 male, Feb. 18, 2002, F. Rego leg. (INPA); $80 \mathrm{~km}$ from Manaus, Fazenda Porto Alegre, 1 male, 19891992, H.G. Fowler leg. (IBSP 39399), 2 males, Jan. 21-23, 2002, F. Rego leg. (INPA); Reserva Colosso, 2 females, Feb., 1990 - Mar., 1991, H.G. Fowler, E.M. Venticinque \& R. Vieira leg. (IBSP 39394, MCZ); Reserva Cabo Frio, 1 female, May 16, 1990, H.G. Fowler, E.M. Venticinque \& R. Vieira leg. (MCZ), 1 male, Mar. 13, 2002, F. Rego leg. (INPA); $50 \mathrm{~km}$ from Manaus, Fazenda Esteio, Feb. 6, 1986, B.C. Klein leg. (UA); Pará: Jacareacanga, 1 male and 1 female, Dec. 1968, M. Alvarenga leg. (AMNH); Juruti, Platô do Rio Juruti, Igarapé Mutum (02 $36^{\prime} 45.2^{\prime \prime}$; $\left.56^{\circ} 11^{\prime} 27.5^{\prime \prime} \mathrm{W}\right), 6$ male and 1 female, Sept. 5-14, 2002, Bonaldo \& Guimarães leg. (MPEG 0401, 0402, 0403, 0405, 0407, 0409, 0411).

\section{Scytodes tinkuan sp. nov. Figs 4-6}

Types. Female holotype and female paratype from Parque Nacional da Serra do Divisor, Acre, Brazil, Mar. 15, 1997, L. Resende \& R.S. Vieira leg., deposited in IBSP 12364.

Etymology. The specific name is a noun in aposition taken from the Amazonian folklore. "Tinkuan" is believed to be an enchanted bird that when sings predicts death.

Diagnosis. The females of $S$. tinkuan sp. nov. are distinguished from the remaining Amazonian species by the u-shaped positioning ridges (Fig. 5) and by the fused posterior hyaline pockets laterally extending below the epyginal pouch limits (Fig. 6).

Description. Male. Unknown.

Female (holotype). Carapace orange, medialy lighter, with brown pattern as shown on figure 4 . Chelicerae orange with dorsal longitudinal brown stripe. Pedipalps orange. Palpal femora with scattered brown stains and palpal tibiae with prolateral and dorsal brown stripes. Labium pale yellow, brown at base. Endites uniformly yellow. Sternum pale yellow with brown margins in front of each coxae and labium. Legs yellow. Femora I-IV with ventral pair of longitudinal brown stripes. Tibiae I-IV with median transversal brown band and brown ends. Abdomen grayish with black pattern (Fig. 4). Total length 3.80. Carapace domed, 1.90 long, 1.70 wide. Eye diameters: PME 0.12, ALE 0.12, PLE 0.14. Lateral eyes on a tubercle. Chelicerae with subapical hyaline keel and 5 conspicuous stridulatory ridges. Labium 0.14 long, 0.18 wide. Sternum 0.92 long, 0.80 wide. leg measurements: I - femur $2.70 /$ patella $0.50 /$ tibia 2.80 /metatarsus $3.30 /$ tarsus $0.70 /$ total $10.00 / \mathrm{II}-2.00 / 0.50 / 2.00 /$ 2.30/0.60/7.40/III - 1.30/1.40/0.50/1.40/0.50/5.10/IV - 2.00/ 


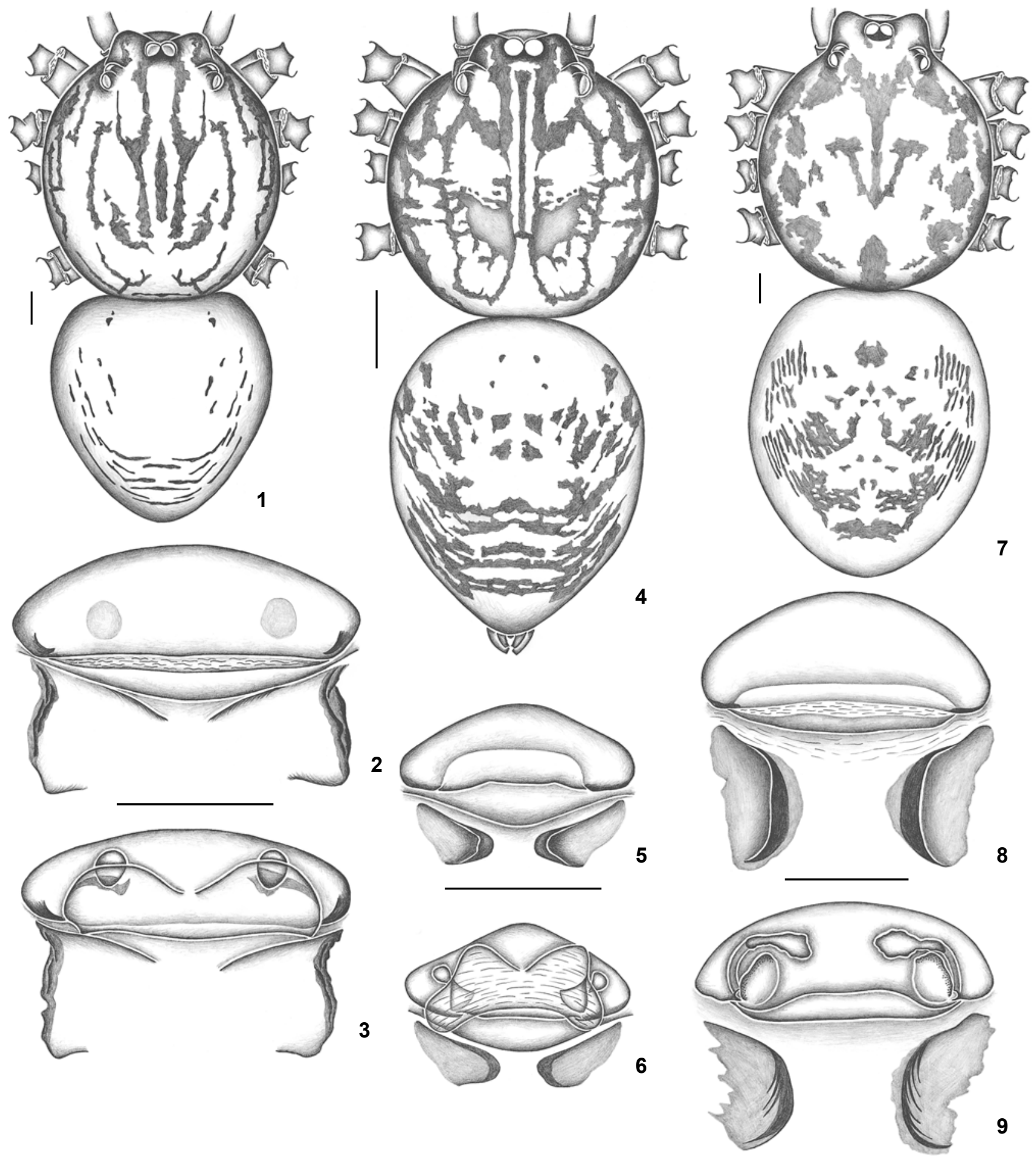

Figures 1-9. (1-3) Scytodes altamira: (1) female, body, dorsal view; (2) epigynum, ventral view; (3) dorsal view; (4-6) S. tinkuan sp. nov.: (4) female, body, dorsal view; (5) epigynum, ventral view; (6) dorsal view; (7-9) S. mapinguari sp. nov.: (7) female, body, dorsal view; (8) epigynum, ventral view; (9) dorsal view. Scale lines: $0.5 \mathrm{~mm}$. 
0.50/1.90/2.10/0.60/7.10. Palpal femur with stridulatory pick short and stout on rounded and slightly projected socket. Epigynum with u-shaped positioning ridges and foveas separated from each other by half their width (Fig. 5). Internal genitalia with one small round spermathecae on each side and hyaline pocket with anterior sclerotinized area on each side. Copulation ducts inconspicuous (Fig. 6). Abdomen 1.90 long, 1.60 wide, covered with slender hairs.

Variation: 2 females. Total length: 3.50-3.80; Carapace: 1.60-1.90; femur I: 1.90-2.70.

Distribution. Only known from the type locality. Material examined. Only the types.

\section{Scytodes mapinguari sp. nov. Figs 7-9}

Types. Female holotype from Ilha de Maracá, Roraima, Brazil, Feb. 4, 1991, A.B. Bonaldo leg., deposited in MCTP 1826; Paratypes: 1 male and 2 juveniles, Gruta do Batismo (MZSP 21852); 2 females, Gruta Refúgio do Maroaga (IBSP 40862; MZSP 21851); close to Gruta Refúgio do Maroaga (IBSP 40825; MZSP 21850), all from Presidente Figueiredo, Manaus, Amazonas, Brazil, Aug. 23-31, 2003, R. Pinto da Rocha leg.; 1 female, Estação Científica Ferreira Penna, Flona Caxiuanã, Melgaço, Jul. 14, 2002, A.B. Bonaldo leg. (MPEG 0914).

Etymology. The specific name is a noun in apposition taken from the Amazonian folklore. "Mapinguari" is a giant, hairy monster with a single eye on his forehead and a vertical mouth that reaches his belly button. He is considered a protector of the forest.

Diagnosis. The females of $S$. mapinguari sp. nov. are distinguished from the remaining Amazonian species by the pearshaped spermathecae, slightly sclerotinized and with very long copulation ducts and by the small oval hyaline pocket (Fig. 9).

Description. Male. Unknown.

Female (holotype) Carapace orange with brown pattern, as shown on figure 7 . Chelicerae orange with large dorsal brown stain at base. Pedipalps transversally striped orange and brown. Labium and endites orange, retrolaterally brown. Sternum orange with slightly darker margins and brown stains in front of each coxae. Legs transversally striped, as pedipalps. Abdomen grayish with black pattern (Fig. 7). Total length 7.20. Carapace domed, 3.40 long, 2.70 wide. Eye diameters: PME 0.16, ALE 0.18 , PLE 0.16. Lateral eyes on a tubercle. Chelicerae with subapical hyaline keel and 7 stridulatory ridges. Labium 0.32 long, 0.48 wide. Sternum 1.88 long, 1.18 wide. leg measurements: I - femur 6.20/patella 0.80/tibia 6.50/metatarsus 8.10 /tarsus 1.30 / total 22.90/II - 5.00/0.80/4.90/5.90/1.20/17.80/III - 3.30/0.80/ 3.60/3.90/1.10/12.70/IV - 5.00/0.80/4.90/5.20/1.20/17.10. Palpal femur with stridulatory pick short and stout on rounded socket. Epigynum with half-moon shaped positioning ridges and foveas separated from each other by one and a half times their width (Fig. 8). Abdomen 3.80 long, 3.10 wide, covered with slender hairs.
Variation. 6 females. Total length: 5.20-7.20; carapace: 2.40-4.00; femur I: 5.20-7.10.

Distribution. Northern Brazil, states of Amazonas and Roraima.

Material examined. Brazil, Pará: Melgaço, Estação Científica Ferreira Penna, FLONA Caxiuanã, 1 female, Jul. 14, 2002, A.B. Bonaldo leg. (MPEG 0915); Monte Alegre, 1 female, Jun. 16, 2001, A.B. Bonaldo leg. (MPEG 0521).

\section{Scytodes iara sp. nov. Figs $10-12$}

Types. Female holotype from Rio Urucu (04'51'56"S; 6504'56"W), Coari, Amazonas, Brazil, Jan. 25 - Feb. 10, 1995, P.F. Bührnheim et al. leg., deposited in UA. Paratype: 1 female, Rio Urucu (0450'73"S; 6502'37"W), Coari, Amazonas, Brazil, Aug. 14-25, 1993, P.F. Bührnheim \& N.O. Aguiar leg. (IBSP 41917).

Etymology. The specific name is a noun in aposition taken from the Amazonian folklore. "Iara" is a beautiful dark haired woman with a dazzling body and a melodic voice that bewitches all that hear it. She is held responsible for boat accidents and child disappearances.

Diagnosis. The females of $S$. iara sp. nov. are distinguished from the remaining Amazonian species by the very small spermathecae and by the lack of hyaline pockets (Fig. 11).

Description. Male. Unknown.

Female (holotype). Carapace orange with dark brown pattern, as shown on figure 10 . Chelicerae orange with transversal brown stripe. Pedipalps orange. Palpal femora and tibiae with prolateral brown stripe. Labium and endites brown, distally lighter. Sternum pale yellow with median brown stain and brown stains in front of each coxae. Legs tranversally striped brown and orange, except tarsi and patellae, uniformly orange. Abdomen grayish with sparce dark brown pattern (Fig. 10). Total length 2.20. Carapace domed, 1.05 long, 1,00 wide. Eye diameters: PME 0.07, ALE 0.07, PLE 0.07. Lateral eyes on a tubercle. Chelicerae with subapical hyaline keel and inconspicuous stridulatory ridges. Labium 0.12 long, 0.19 wide. Sternum 0.52 long, 0.52 wide. leg measurements: I - femur $0.90 /$ patella $0.30 /$ tibia $0.84 /$ metatarsus $0.84 /$ tarsus $0.34 /$ total $3.22 / \mathrm{II}-0.76$ / 0.30/0.66/0.72/0.28/2.72/III - 0.62/0.30/0.54/0.58/0.24/2.88/IV $-0.78 / 0.30 / 0.72 / 0.82 / 0.26 / 2.88$. Palpal femur with stridulatory pick short and stout with rounded socket. Epyginum with epigynal pouch slightly triangular. Crescent moon shaped positioning ridges and foveas separated from each other by more than ten times their with (Fig. 11). Internal genitalia with small spermathecae with long and narrow copulation ducts (Fig. 12). Abdomen 1.15 long, 1.10 wide, covered with sparse spatulated hairs.

Variation. 2 females. Total length: 2.20-2.40; carapace: 1.05-1.10.

Distribution. Only known from the type locality.

Material examined. Only the types. 

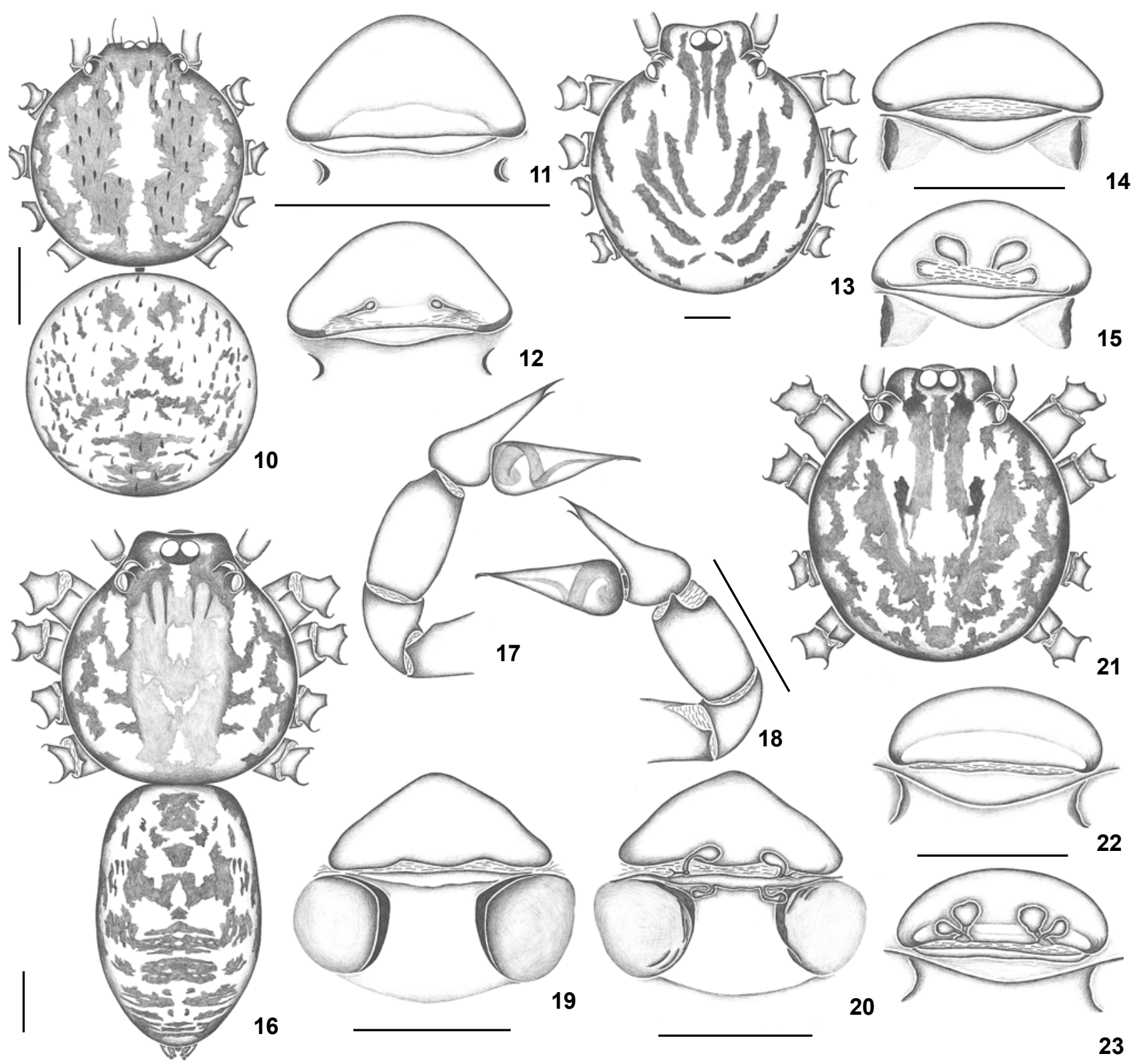

22

Figures 10-23. (10-12) Scytodes iara sp. nov.: (10) female, body, dorsal view; (11) epigynum, ventral view; (12) dorsal view; (13-15) S. saci sp. nov.: (13) female, carapace, dorsal view; (14) epigynum, ventral view; (15) dorsal view; (16-20) S. curupira sp. nov.: (16) male, body, dorsal view; (17) left palp, prolateral view; (18) retrolateral view; (19) female, epigynum, ventral view; (20) dorsal view; (21-23) S. jurupari sp. nov.: (21) female, carapace, dorsal view; (22) epigynum, ventral view; (23) dorsal view. Scale lines: $0.5 \mathrm{~mm}$.

\section{Scytodes saci sp. nov.}

Figs 13-15

Types. Female holotype from Ilha de Maracá, Roraima, Brazil, Feb. 4, 1991, A.B. Bonaldo leg., deposited in MCTP (ex-1966).

Etymology. The specific name is a noun in aposition taken from the Amazonian folklore. "Saci" is a small entity that protects the forest by scaring hunters away. He is also known for his mischief and his pranks.

Diagnosis. The females of $S$. saci resemble those of $S$. championi F.O.P.-Cambridge (Brescovit \& Rheims 2001: 317, fig. 17) by the shape of the spermathecae. They differ by the slightly rectangular hyaline pockets (Fig. 15) and by the straight posi-

Revista Brasileira de Zoologia 21 (3): 525-533, setembro 2004 
tioning ridges (Fig. 14).

Description. Male. Unknown.

Female (holotype). Carapace yellow with brown pattern as shown in figure 13. Chelicerae yellow with dorsal longitudinal black stripe. Pedipalps cream coloured with prolateral black stripe. Palpal tibiae with prolateral and dorsal black stripe. Labium and endites cream coloured. Sternum cream coloured with black margins in front of each coxae. Legs yellowish. Femora IIV with pair of ventral longitudinal interrupted black stripes. Tibiae I-IV with dark ends and median transversal black band. Abdomen cream coloured. Anterior half mottled with black spots. Posterior half with three transversal irregular black stripes. Total length 4.60. Carapace domed, 2.40 long, 2.10 wide. Eye diameters: PME 0.12, ALE 0.16, PLE 0.18. Lateral eyes on a tubercle. Chelicerae with subapical hyaline keel and inconspicuous stridulatory ridges. Labium 0.20 long, 0.30 wide. Sternum 1.20 long, 0.94 wide. leg measurements: I - femur 5.00/patella 0.70/tibia 5.00/metatarsus 6.20/tarsus 0.90/total 17.80/II - 3.50/0.70/3.40/ 4.10/0.70/12.40/III - 2.40/0.60/1.90/2.40/0.60/7.90/IV - 3.40/ 0.70/3.20/3.70/0.70/11.70. Palpal femur with stridulatory pick long and slender on rounded and projected socket. Epyginum with straight positioning ridges (Fig. 14). Internal genitalia with slightly oval spermathecae, short copulation ducts and slightly rectangular hyaline pockets, distally sclerotinized (Fig. 15). Abdomen 2.20 long, 1.70 wide, covered with slender hairs.

Distribution. Only known from the type locality.

Material examined. Only the holotype.

\section{Scytodes curupira sp. nov. Figs $16-20$}

Types. Male holotype from Barreira do Matupiri, Manicoré, Amazonas, Brazil, Apr. 18, 1996, Equipe IBSP/SMNK leg., deposited in IBSP 8881. Paratypes: 1 male, with the same data as holotype (IBSP 36289); 1 male and 2 females, Porto Velho, Rondônia, Brazil, Apr. 15, 1996, Equipe IBSP/SMNK leg. (IBSP 8703, 8713); 1 female, Reserva Dimona, Manaus, Amazonas, Brazil, Feb. 28, 2002, F. Rego leg. (INPA).

Etymology. The specific name is a noun in aposition taken from the Amazonian folklore. The "Curupira" is a small entity whose body is covered with long hairs and whose feet are turned backwards. It is considered a protector of the forest, killing those who hunt for sport but protecting those who hunt for survival.

Diagnosis. Scytodes curupira sp. nov. resembles $S$. fusca Walckenaer by the male palp with a slender embolus and no distal projections or membranes (Figs 17-18, BRIGNOLI 1976: 174, fig. 110, BREsCovit \& Rheims 2000: 321, figs 5-6) and by the shape of the females' epigynum fovea (Fig. 19, Brignoli 1976: 174, fig. 107, BRescovit \& Rheims 2000: 321, fig. 7). They differ by the smaller size, straight tipped bulb of the male palp (Figs 1718) and by the presence of two pairs of oval spermathecae, one slightly larger and above the posterior limits of the epigynal pouch and the other upside down and below the posterior limits of the epigynal pouch (Fig. 20).
Description. Male (holotype) Carapace pale yellow with dark brown pattern, as shown on figure 16. Chelicerae pale yellow, brown at base. Pedipalps pale yellow, brown at distal end of articules. Labium brown. Endites pale yellow. Sternum brown, slightly lighter towards the center. Legs pale yellow with transversal brown bands. Abdomen grayish with black pattern (Fig. 16). Total length 3.30. Carapace slighlty domed, 1.60 long, 1.40 wide. Eye diameters: PME 0.12, ALE 0.14, PLE 0.14 . Lateral eyes on a tubercle. Chelicerae with subapical hyaline keel and 7 stridulatory ridges. Labium 0.20 long, 0.20 wide. Sternum 0.94 long, 0.76 wide. leg measurements: I - femur 4.60/ patella $0.50 /$ tibia $4.70 /$ metatarsus $5.00 /$ tarsus $0.90 /$ total $15.70 /$ II $-3.60 / 0.50 / 3.40 / 4.10 / 0.90 / 12.50 / \mathrm{III}-2.40 / 0.50 / 1.90 / 2.30 /$ 0.70/7.80/IV - 3.40/0.50/3.20/3.50/0.90/11.50. Palpal femur with stridulatory pick short and stout on rounded and projected socket. Cymbium with a pair of strong distal spines, one slightly below the other. Bulb 0.42 long, gradually narrowed towards the straight, but slightly twisted tip (Figs 1718). Abdomen 1.70 long, 1.00 wide, covered with slender hairs.

Female. (IBSP 32269). Coloration pattern as in male. Total length 4.30. Carapace domed, 2.30 long, 1.60 wide. Eye diameters: PME 0.12, ALE 0.12, PLE 0.12. Lateral eyes on a tubercle. Chelicerae as in male. Labium 0.22 long, 0.30 wide. Sternum 1.06 long, 0.84 wide. leg measurements: I - femur 2.90/patella $0.50 /$ tibia 2.80 /metatarsus 3.20 /tarsus $0.80 /$ total $10.20 / \mathrm{II}-2.50$ / 0.50/2.20/2.60/0.80/8.60/III - 1.70/0.50/1.40/1.60/0.70/5.90/IV - 2.50/0.50/2.10/2.40/0.80/8.30. Palpal femur as in male. Epigynum with slightly triangular epigynal pouch, moon shaped, narrow positioning ridges and rounded foveas, separated from each other by their width (Fig. 19). Abdomen 2.00 long, 1.80 wide, as in male.

Variation. 3 males. Total length: 3.30-3.50; carapace: $1.50-$ 1.60; femur I: 4.40-4.60; bulb: 0.38-0.42. 3 females. Total length: 4.00-5.20; carapace: 2.10-2.30; femur I: 2.90-3.40.

Distribution. Northern Brazil, states of Amazonas and Rondônia.

Material examined. Only the types.

\section{Scytodes jurupari sp. nov.}

Figs 21-23

Types. Female holotype from Reserva Extrativista de Catuaba, Senador Guiomar, Acre, Brazil, Jun. 25, 2001, E. Morato leg., deposited in IBSP 40828. Paratype: 1 female, with the same locality and collector, Jul. 31, 2001 (IBSP 40829).

Etymology. The specific name is a noun in aposition taken from the Amazonian folklore. "Jurupari" is one of many indian demons, but was used by the jesuits to represent the "Devil", as known in Christianity.

Diagnosis. The females of $S$. jurupari sp. nov. are distinguished from the remaining Amazonian species by the presence of a pair of spermathecae, the anterior slightly larger and straight and the posterior directed outwards (Fig. 23).

Description. Male. Unknown. 
Female (holotype). Carapace orange with brown pattern, as shown on figure 21 . Chelicerae pale orange with longitudinal dorsal brown stripe. Pedipalps pale orange with a prolateral dark brown stripe. Tibiae with a dorsal brown stripe. Labium pale yellow, brown at base. Endites uniformly pale yellow. Sternum pale yellow with dark brown margins in front of each coxae and brown stains extending towards the center. Legs orange. Femora I-IV with three ventral longitudinal black stripes. Patellae I-IV dark brown at base. Tibiae I-IV with black ends and longitudinal black stripe. Abdomen cream colored with anterior pair of brown inverted v-shaped lines and three posterior transversal stripes. Total length 5.90. Carapace domed, 2.50 long, 2.00 wide. Eye diameters: PME 0.14, ALE 0.14, PLE 0.14 . Lateral eyes on a tubercle. Chelicerae with subapical hyaline keel and five slightly conspicuous stridulatory ridges. Labium 0.16 long, 0.30 wide. Sternum 1.22 long, 0.94 wide. leg measurements: I - femur 3.80/patella 0.60/tibia 4.30/metatarsus $4.80 /$ tarsus $0.90 /$ total $14.40 / \mathrm{II}-2.80 / 0.60 / 2.90 / 3.40 / 0.60 /$ 10.30/II - 1.90/0.60/1.80/2.00/0.50/6.80/IV - 2.80/0.60/2.60/ $2.70 / 0.60 / 9.30$. Palpal femur with stridulatory pick long and strong on rounded and projected socket. Epigynum with very thin moon shaped positioning ridges and very slightly conspicuous fovea (Fig. 22). Abdomen 3.40 long, 2.80 wide, covered with slender hairs.

Variation. Two females. Total length: 4.60-5.90; carapace: 2.20-2.50; femur I: 3.80-4.00.

Distribution. Only known from the type locality.

Material examined. Only the types.

\section{Scytodes caure sp. nov.} Figs 24-26

Types. Female holotype from Reserva do Km 41, BR 174, $80 \mathrm{Km} \mathrm{N}$ from Manaus, Amazonas, Brazil, Aug., 2000, A.J. Santos leg., deposited in IBSP 26214. Paratype: 1 female, Reserva Dimona, BR 174, $80 \mathrm{Km} \mathrm{N}$ from Manaus, Amazonas, Brazil, Feb. 26, 2003, F. Rego leg. (INPA).

Etymology. The specific name is a noun in aposition taken from the Amazonian folklore. "Cauré" is a small enchanted bird that symbolizes happyness and fortune. It is considered a good luck sign.

Diagnosis. The females of $S$. caure sp. nov. are distinguished from the remaining Amazonian species by the internal genitalia with very large, slightly conical posterior hyaline pockets with a slightly triangular sclerotinized lateral area (Fig. 26).

Description. Male. Unknown.

Female (paratype). Carapace yellow, lighter at centre, with dark brown pattern, as shown on figure 24 . Chelicerae pale yellow with dorsal longitudinal brown stripe. Pedipalps pale yellow. Palpal femora and tibiae with prolateral longitudinal brown stripes. Palpal patellae with brown ends. Labium and endites pale yellow, brown at base Sternum cream coloured with dark brown margins in front of each coxae an a pair of iregular dark brown stains at centre. Legs pale yellow with ventral longitudinal brown stains and brown distal ends, except tarsi uniformly yellow. Abdomen pale yellow with black pattern (Fig. 24). Total length 3.40. Carapace slightly domed, 1.70 long, 1.40 wide. Eye diameters: PME 0.10, ALE 0.12, PLE 0.12. Lateral eyes on a tubercle. Chelicerae with subapical hyaline keel and inconspicuous stridulatory ridges. Labium 0.16 long, 0.26 wide. Sternum 0.98 long, 0.80 wide. leg measurements: I - femur 4.90/patella 0.50/tibia 4.80/metatarsus 5.30/tarsus 0.70 / total 16.20/II - 3.60/0.50/3.10/3.60/0.50/11.30/III - 2.00/0.40/ 1.70/2.10/0.50/6.70/IV - 3.50/0.50/3.00/3.50/0.60/11.10. Palpal femur with stridulatory pick long and slender on rounded and slightly projected socket. Epigynum with slightly rectangular epigynal pouch and widely separated, straight positioning ridges (Fig. 25). Internal genitalia with oval spermathecae and very large hyaline pockets, completely covering the copulation ducts (Fig. 26). Abdomen 1.70 long, 1.00 wide, covered with slender hairs.

Variation. Two females. Total length: 3.40-3.60; carapace: 1.70-1.80; femur I: 4.90-5.20.

Distribution. Northern Brazil, state of Amazonas.

Material examined. Only the types.

\section{Scytodes caipora sp. nov. Figs 27-29}

Types. Female holotype from Reserva Extrativista de Catuaba, Senador Guiomar, Acre, Brazil, Aug. 31, 2001, E. Morato leg. deposited in IBSP 40827.

Etymology. The specific name is a noun in aposition taken from the Amazonian folklore. "Caipora" is a small indian, whose hair is the color of fire, that rides wild pigs and protects the forest and it's animals.

Diagnosis. The females of $S$. caipora sp. nov. are distinguished from the remaining Amazonian species by their minute size, the horseshoe shaped positioning ridges (Fig. 28) and by the large oval spermathecae surpassing the anterior limits of the epigynal pouch (Fig. 29).

Description. Male. Unknown.

Female (holotype). Carapace pale orange with dark brown pattern as shown on figure 27. Chelicerae yellow, brown at base. Labium brown, distally orange. Endites yellow, brown at base. Sternum brown with slightly darker borders. Legs and pedipalps orange with transversal brown bands. Abdomen cream colored with brown pattern (Fig. 27). Total length 2.00. Carapace domed, 1.00 long, 0.90 wide. Eye diameters: PME 0.06, ALE 0.06, PLE 0.06. Lateral eyes on a tubercle. Chelicerae with subapical hyaline keel and inconspicuous stridulatory ridges. Labium 0.08 long, 0.14 wide. Sternum 0.52 long, 0.52 wide. leg measurements: I - femur $0.80 /$ patella $0.24 /$ tibia $0.80 /$ metatarsus $0.88 /$ tarsus $0.32 /$ total $3.04 / \mathrm{II}-0.64 / 0.26 / 0.64 / 0.74$ / $0.38 / 2.66 /$ III $-0.56 / 0.24 / 0.44 / 0.56 / 0.24 / 2.04 / \mathrm{IV}-0.80 / 0.30 /$ $0.62 / 0.88 / 0.26 / 2.86$. Palpal femur with stridulatory pick short 


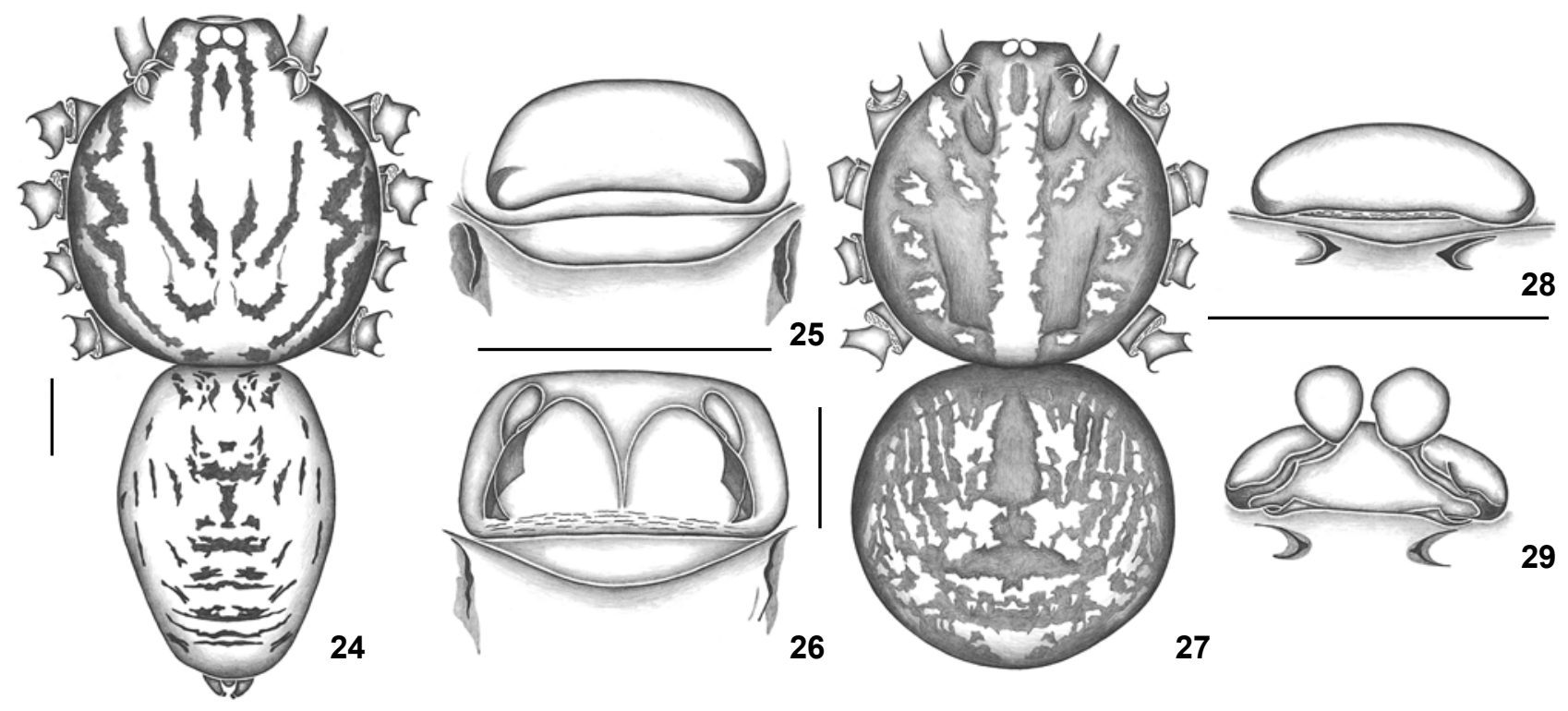

Figuras 24-29. (24-26) Scytodes caure sp. nov.: (24) female, body, dorsal; (25) epigynum, ventral view; (26) dorsal view; (27-29) S. caipora sp. nov.: (27) female, body, dorsal view; (28) epigynum, ventral view; (29) dorsal view. Scale lines: $0.5 \mathrm{~mm}$.

and stout on rounded and slightly projected socket. Epigynum foveas separated from each other by twice their width (Fig. 28). Internal genitalia with large spermathecae, very long copulation ducts and no hyaline pockets (Fig. 29). Abdomen 1.00 long, 1.00 wide, rounded sparsely covered with spatulated hairs. Distribution. Only known from the type locality.

Material examined. Only the holotype.

\section{New records}

Scytodes auricula Rheims \& Brescovit, 2000 - BRAzIL, Amazonas: Forquilha, Parque Nacional Jaú, 1 male and 2 females, Jun. 27, 2000, E.M. Venticinque leg. (IBSP 36475); Coari, Porto Urucu, Rio Urucu, 6 males and 6 females, Jul. 14-24, 2003, Bonaldo, Guimarães \& Dias leg. (MPEG 0589, 0590, 0591, 0593, 0594, 0595, 00599, 0600, 0603, 0604, 0607). Acre: Rio Branco, Reserva Extrativista de Catuaba, 11 males, 21 females and 9 juveniles, 2001-2002, E. Morato leg. (IBSP 38434-38436, 4114841162, 41165). Pará: Jurutí, Plateau do Rio Juruti, Igarapé Mutum (02 ${ }^{\circ} 36^{\prime} 10.6^{\prime \prime}$ S, 56 $\left.12^{\prime} 25.8^{\prime \prime} \mathrm{W}\right), 1$ female, Sept. 6, 2002, A.B. Bonaldo leg. (MPEG 0399); Senador José Porfírio, margem direita do Rio Xingu, 1 male, Feb, 22, 2001, Equipe MPEG (MPEG 0500).

Scytodes championi F.O.P.-Cambridge, 1899 -Brazil. Pará: Almeirim, Reserva Genética do Pacamari, 2 females, Feb. 22, 2003, Barreiros \& Guimarães leg. (MPEG 0347-0348).

Scytodes fusca Walckenaer, 1837 - BRAzIL, Roraima: Rio Sumuru, 1 female, Oct., 1966, M. Alvarenga leg. (MZSP 8559); Pará: Belém, Parque Municipal de Belém, 1 female, Feb. 12, 1959, A.M. Nadler leg. (AMNH), Canindé, Rio Gurupi, 1 female, Dec. 1-5, 1964, B. Malkin leg. (AMNH), 1 female, Feb.-May, 1964, J.
Carvalho leg. (AMNH); São Geraldo do Araguaia, Serra das Andorinhas, 1 male, Dec. 4, 2001, D.D. Guimarães (MPEG 0468). Scytodes longipes Lucas, 1844 - BraziL, Pará: Belém, Parque Municipal de Belém, 1 male, Feb. 12, 1959, A.M. Nadler leg. (AMNH).

Scytodes martiusi Brescovit \& Höfer, 1999 - BrazIL, Amazonas: $80 \mathrm{Km}$ from Manaus, Reserva Dimona, 6 males, 11 femlaes and 5 juveniles, 1989-1992, H.G. Fowler, E.M. Venticinque \& R. Vieira leg. (IBSP 39385-39391; MCZ)

Scytodes piroca Rheims \& Brescovit, 2000 - BRAZIL, Amazonas: $80 \mathrm{Km} \mathrm{N}$ of Manaus, BR 174, Reserva do Km 41, 3 males, 27 females and 2 juveniles, 1989-1992, H.G. Fowler, E.M. Venticinque \& R. Vieira leg. (IBSP 39367-39371, 39373-39374, 39376-39384; MCZ); Reserva Florestal, 2 females, 1989-1992, H.G. Fowler, E.M. Venticinque \& R. Vieira leg. (IBSP 39400; MCZ); Reserva Colosso, 2 males, 7 females and 1 juveniles, 1989-1992, H.G. Fowler, E.M. Venticinque \& R. Vieira leg. (IBSP 39392-39393, 39395-39398; MCZ); Fazenda Cabo Frio, 1 male and 2 females, 1989-1992, H. G. Fowler, E. M. Venticinque \& R. Vieira leg. (MCZ); Rondônia: Costa Marques, 1 female, Jan. 17-18, 2002, E. Ramires leg. (IBSP 36965).

Scytodes romitii Caporiacco, 1947 - Brazil, Amazonas: Forquilha, Parque Nacional Jaú, 1 male and 2 females, Jun. 2728, 2000, E. M. Venticinque leg. (IBSP 36473-36474); Coari, Paraná Apaurá, 3 males, Sept. 24, 2003, Venticinque et al. leg. (IBSP), Trocaris, 2 males and 1 females, Sept. 25, 2003, Venticinque et al. leg. (IBSP, MPEG, INPA), Porto Urucu, Rio Urucu, 2 females, Jul. 16-19, A.B. Bonaldo leg. (MPEG 0592, 0601); Codajás, Lago do Poção, 1 female, Sept. 27, 2003, 
Venticinque et al. leg. (IBSP); Itacoatiara, Ilha do Soreano, 2 females, Nov. 6, 2003, Venticinque et al. leg. (MPEG, INPA), Trindade, 1 male, Nov. 6, 2003, Venticinque et al. leg. (IBSP); Juruá, Ilha da Consciência, 1 female, Sept. 19, 2003, Venticinque et al. leg. (IBSP), Lago Tamaniqua, 1 female, Sept. 19, 2003, Venticinque et al. leg. (IBSP), Paraná Teiú, 1 male and 1 female, Sept. 19, 2003, Venticinque et al. leg. (IBSP, INPA); Jutaí, Ilha do Xibeco, Restinga do Cevalho, 1 female, Sept. 17, 2003, Venticinque et al. leg. (IBSP); Manacapuru, 1 female, Sept. 29, 2003, Venticinque et al. leg. (IBSP); Santo Antonio do Iça, Ilha do Espanhol, 1 male, Sept. 15, 2003, Venticinque et al. leg. (IBSP), Paraná Canini, Lago Chicotuba, 1 male and 1 female, Sept. 15, 2003, Venticinque et al. leg. (IBSP, MPEG); Tefé, 1 male, Sept. 23, 2003, Venticinque et al. leg. (IBSP); Urucurituba, Costa do Cucuiari, 6 males, Nov. 4, 2003, Venticinque et al. leg. (INPA, IBSP), Ressaca da Iracema, 1 male, Nov. 5, 2003, Venticinque et al. leg. (IBSP). Acre: Senador Guiomar, Reserva Extrativista de Catuaba, 2 females, Jun.-Jul., 2001, E. Morato leg. (IBSP 4116341164). Pará: Barcarena, Reserva Samaúma (0120'43"S, $\left.48^{\circ} 42^{\prime} 36^{\prime \prime} \mathrm{W}\right), 6$ males and 4 females, Nov. 15-20, 2001, Dias, Guimarães \& Bonaldo leg. (MPEG 0265, 0266, 0271, 0278, 0279, 0306), Igarapé Tauá $\left(01^{\circ} 36^{\prime} \mathrm{S}, 48^{\circ} 43^{\prime} \mathrm{W}\right), 1$ female, Nov. 20, 2001 , L.A. Quaresma leg. (MPEG 0273); Juruti, Margem do Rio Amazonas ( $\left.02^{\circ} 24^{\prime} 33.2^{\prime \prime} \mathrm{S}, 56^{\circ} 26^{\prime} 10.6^{\prime \prime} \mathrm{W}\right), 2$ males and 1 female, Sept. 18, 2002, A.B. Bonaldo leg. (MPEG 0400, 0404); Melgaço, Estação Científica Ferreira Penna, FLONA Caxiuanã, 1 female, Jul. 14, 2002, C. Pereira leg. (MPEG); Gurupá, Furinho, 1 male, Oct. 18, 2003, Venticinque et al. leg. (IBSP), São José, 1 female, Oct. 18, 2003, Venticinque et al. leg. (MPEG).

Scytodes vieirae Rheims \& Brescovit, 2000 - BrazIL, Amazonas: $80 \mathrm{~km} \mathrm{~N}$ from Manaus, BR 174, Reserva do Km 41, 2 males, Mar. - May, 1991, H.G. Fowler, E.M. Venticinque \& R. Vieira leg. (IBSP 39375; MCZ).

\section{ACKNOWLEDGEMENTS}

We wish to thank Miguel Simó for helpful comments on the manuscript. This study was supported by $\mathrm{CNPq}$ and
"Fundação de Amparo à Pesquisa de São Paulo" (FAPESP 02/ 11277-9; 99/05446-8).

\section{REFERENCES}

Ав'S $\mathrm{ABER}$, A. 2003. Os domínios de natureza no Brasil. Potencialidades paisagísticas. São Paulo, Ateliê Editorial, $160 \mathrm{p}$.

Brescovit, A.D. \& H. Höfer 1999. Four new species of litter inhabiting Scytodes spiders (Araneae, Scytodidae) from Amazonia. Studies of Neotropical Fauna and Environment, Lisse, 34: 105-113.

BResCovit, A.D. \& C.A. Rheims 2000. On the synanthropic species of the genus Scytodes Latreille (Araneae, Scytodidae) of Brazil, with synonymies and records of these species in other Neotropical countries. Bulletin of the British Arachnological Society, Dorset, 11 (8): 320-330.

. 2001. Notes on the genus Scytodes Latreille (Araneae, Scytodidae) in the Central and South Americas. Journal of Arachnology, Denver, 29 (3): 312-329.

Brignoli, P.M. 1976. Beiträge zur Kenntnis der Scytodidae (Araneae). Revue Suisse de Zoologie, Genéve, 83 (1): 125 191.

Fernandes, A. 1998. Fitogeografia brasileira. Fortaleza, Multigraf Editora, 340p.

Platnick, N.I. 2003. The world spider catalog version 3.5. American Museum of Natural History, online at http:// research.amnh.org/entomology/spiders/catalog81-87/ index.html, acesso em 07/VI/2004.

Rheims, C.A. \& A.D. Brescovit. 2000. Six new species of Scytodes Latreille, 1804 (Araneae, Scytodidae) from Brazil. Zoosystema, Paris, 22 (4): 719-730.

. 2001a. Three new species of litter inhabitig spiders of the genus Scytodes Latreille from northeastern Brazil. Spixiana, München, 24 (2): 123-128.

.2001b. New species and records of Scytodes Latreille, 1804 of the "globula group" from Brazil (Araneae, Scytodidae). Andrias, Karlsruhe, 15: 91-98.

Received in 02.III.2004; accepted in 16.VII.2004. 